\title{
Media usage profile of adolescents in varied economic background
}

\author{
Maheshwar Mekam ${ }^{1 \star}$, Sylvia Fernandez Rao ${ }^{1}$, Jagdish Buwade ${ }^{1}$, Narender Karnam² and \\ Balakrishna Nagalla ${ }^{3}$
}

\author{
${ }^{1}$ Extension and Training Division, Indian Council of Medical Research (ICMR), National Institute of Nutrition, Hyderabad, \\ India. \\ ${ }^{2}$ Department of Communication and Journalism, Osmania University, Hyderabad, India. \\ ${ }^{3}$ Statistics Division, Indian Council of Medical Research (ICMR), National Institute of Nutrition, Hyderabad, India.
}

Received 9 August, 2020; Accepted 25 March, 2021

\begin{abstract}
Media plays an important role in social development and teenagers are the future of the society. This study made an attempt to elicit responses from teenagers on media content by projecting questions such as; what kind of content are teenagers viewing/reading mostly? What are their favourite programmes; Do they search for any information about nutrition and health related matters? What is the primary source of information for teenagers about health and nutrition?; and how do they spend their leisure-time? This cross-sectional study adopted stratified random sampling from three types of economic groups using a self-administered questionnaire as a tool for data collection. Results revealed that parents and Internet are serving as primary source of health and nutrition information for teenagers. Teenagers of poor families' have low access to Internet, which manifests the glaring 'digital divide'. Contrary to this, boys of poor families watching porn visuals is significantly highest compared to all strata of boys and girls, which clearly indicates the misuse of Internet by boys of poor families. This study recommends that parents, the media, health practitioners and policy makers, among others look into possible ways of increasing the benefits and reducing the harm that media can have on the development of children and adolescents.
\end{abstract}

Key words: Mass media, teenagers, economic background, digital divide, health and nutrition information.

\section{INTRODUCTION}

Media content is defined as a mix of spot news, analysis, awareness messages that culminate into some kind of audio, and visual forms for public consumption (Lee Odden, 2014). Media content as a product is meticulously packaged with a mixture of relativity, excitement and enjoyment plus a tinge of emotion to share (Keinan and
Kivetz, 2011).

Content comes in many forms (audio, text, video), and it aims to inform, entertain, enlighten, or teach all those who consume it. Hence, efforts are made to make the content engaging, relevant, reliable, interesting, entertaining or enlightening in the form of text, image,

\footnotetext{
${ }^{*}$ Corresponding author. E-mail: maheswarnin@yahoo.com. Tel: +91-40-27197223, 9989233395.
} 
video or audio (Hallin and Mancini, 2011).

Today's media channels disseminate diverse content. In addition to news, current affairs and analysis of media, it publishes/ broadcasts/ telecasts content pertaining to academic, values, entertainment, and porn as well as suspense thrillers. Most access to the media content in all these including internet is unrestricted (Luscombe, 2016). This poses great danger to young children gaining easy access to adult content and leading to undesirable consequences (Mead, 2016). In addition, McQuail Denis (2005) observes that "whether for children or adults, the media are criticized for offering mindless and soporific entertainment instead of original and stimulating content". In the last two decades, studies have drawn a relationship between exposure to mass media and health-related behaviour (HRB) of teenagers (Mekam, 2016). For instance, Global Adult Tobacco Survey (GATS) conducted during 2009-10 states that close to $9 \%$ of students between the age group of 13-15 years use tobacco (Gupta et al., 2012). GATS report elaborates that $24 \%$ of tobacco users are initiated before 18 years of age.

There are nearly 1.2 billion adolescents (10 - 19 years old) worldwide and in some countries, adolescents make up for nearly one-fourth of the population (WHOAdolescent Health, 2018). This proportion is expected to rise through 2050, particularly in low- and middle-income countries (LMICs). The health of adolescents is more often influenced by the social, emotional and physical environments in which they live and learn. From various critical issues like armed conflict, migration and economic downturns, adolescents are also vulnerable to the risks and opportunities stemming from urbanization and globalization (Blum and Bastos et al., 2012).

There is a lot of interest in the role of media in shaping adolescents' physical and mental health during this period of significant developmental changes, when adolescents exhibit a limited capacity for self-regulation and an increased risk of susceptibility to peer pressure and experimentation (American College of Obstetricians and Gynaecologists, 2016). Because they are in developmental transition, adolescents and young adults (AYAs) are particularly sensitive to influences from their social environments (Sawyer, Bearinger et al., 2012). In a study that examined the extent to which online media activities were associated with the psychological wellbeing of adolescents, it was found that online social networking was adversely associated with self-reported mental problems and suicidal thought (Harris, 2017). The magnitude of the association between social media use and depressive symptoms is significant (Moreno et al., 2018) and this was larger for girls than for boys. Greater social media use was also related to online harassment, poor sleep, low self-esteem and poor body image. These in turn related to higher depressive symptoms (Sabina et al., 2008).

In earlier studies, it was revealed that, social media can be harmful as exposure to porn material on the Internet is common, with $70 \%$ of adolescents aged $15-17$ years reporting accidental exposure and $72 \%$ of college students reporting exposure before age 18 years (Henry, 2001; Springate and Omar, 2013). Further, if sex related communication (sexting), online dating, or other risktaking behaviours are present, the harm gets compounded. Victims of cyber bullying and those who engage in sexting are at increased risk of sexually transmitted infections and pregnancy (American College of Obstetricians and Gynaecologists, 2016). The Internet allows adolescents to explore sexual content with anonymity. This anonymity can embolden adolescents to engage in language and actions they might not engage in during face-to-face encounters. Adolescents who have participated in online dating have been shown to be at increased risk of STIs and high-risk sexual behaviours (Brown and Engle, 2009). Exposure to violent pornographic material has been linked to sexually aggressive behaviours. Data have shown that boys exposed to porn in early adolescence are more likely to engage in sexual harassment in middle adolescence (American Academy of Paediatrics, 2013) and pornography has also been shown to have a negative influence on attitudes and ideas toward women, sexuality and healthy relationships (Springate and Omar, 2013).

Adolescents are also vulnerable to the happenings in the commercial environment, as it relates to food, tobacco and alcohol marketing ( $\mathrm{He}$ et al., 2012; Hanewinkel et al., 2010; Lovato et al., 2011; UNICEF, 2018; Strasburger, 2010). A study (Vijayapushpam et al., 2014) analysed food advertisements in Indian children television and general entertainment channels revealed that television food advertisements in India continue to promote less healthful food products. Another analysis (Mekam et al., 2014) suggests that healthy foods in media are not advertised nearly as much as unhealthy foods, which continues to be a major public health concern.

The influence of the media depends heavily upon the contexts of use; particularly in the family (Buckingham, et al., 2004). The media becomes meaningful in different ways in different contexts. How children use or read a text in private may be very different from how they speak about it with peers, where there may be considerable pressure not to 'take it too seriously'. "Smoking-related media content may have a significant indirect influence on adolescent smoking via its effect on perceived peer norms (Gunther et al., 2006).

However, there are many positive aspects of social media for adolescents and young adults. Scientific technology is a powerful tool to learn more about health. It offers important benefits, such as health promotion, communication, education, and entertainment (Victor et al., 2010). Studies show that adolescents' use of mobile technologies results in improved medication adherence, fewer missed health care appointments and a better 
understanding of their health (IOM and NRC, 2014; O'Keeffe and Clarke-Pearson, 2011; Kelly et al., 2018).

Exposure to the truth campaign in the United States of America was associated with a decreased risk of smoking initiation (relative risk $=0.80, p=0.001$ ) (Farrelly et al., 2009). In the United States, through 2004, approximately 450,000 adolescents were prevented from initiating smoking nationwide using media campaigns. In 2012, the U.S. Centres for Disease Control and Prevention (CDC) TIPS conducted the campaign. Former smokers were shown coping with devastating diseases and disabilities caused by tobacco use. Studies demonstrate that the TIPS campaign is both effective at reducing tobacco use and also extremely cost-effective. A study published in The Lancet (McAfee et al., 2013) estimated that, as a result of the 12-week campaign in 2012, 1.6 million smokers tried to quit smoking and more than 100,000 had quit smoking permanently. Besides, the 2012 campaign inspired millions of non-smokers to encourage friends and family members to quit smoking.

Authors reviewed the most recent research on the effects of media on the health and well-being of children and adolescents (Strasburger, 2010). Studies of their review have shown that media can provide information about safe health practices and can foster social connectedness. "However, recent evidence raises concerns about the media's effects on aggression, sexual behaviour, substance use, disordered eating, and academic difficulties".

In the process of using media, there is high possibility of children coming across different kinds of restricted content (e.g. violence, porn etc). Even in the general content meant for universal viewers or readers, the possibility of children getting exposed to crime and violence based content in addition; cigarette smoking and alcohol consumption are commonly shown among the main actors in the movies and other programmes.

In the midst of 'universe of diverse content' in mass media, this study made an attempt to elicit responses from teenagers on the following questions: (i) What kind of media content teenagers view or read mostly? (ii) What are their favourite programmes? (iii) Do they view or read or search for any information about nutrition and health related matters? If yes, what kind of health and nutrition information do they need? (iv) What is the primary source of information for teenagers about health and nutrition? (v) How do teenagers spend their leisuretime?

\section{MATERIALS AND METHODS}

This is a cross-sectional study with stratified random sampling method comparing three kinds of sections of the society based on their income status viz., lower-economic section, middle-economicsection and higher-economic section as outlined next:

i) Public sector (government) educational institutions (for adolescents of lower-economic families'). ii) Private sector educational institutions (for adolescents of middleeconomic families').

iii) Corporate sector educational institutions (for adolescents of higher-economic families').

A self-administered questionnaire was used as a tool for data collection in this survey.

\section{Calculation of sample}

In India, $70 \%$ of children including males and females are exposed to media with $10 \%$ relative precision (NFHS- 3 Report, 2005-06). Based on these equations, the required sample size for this study was calculated as a cumulative of 155 teenagers per group. Considering three types of economic groups for this study (viz., lower, middle and higher income), the total sample size was rounded to $470(155 \times 3=465)$. The study was conducted in Greater Hyderabad city of Telangana State, India between November 2016 and January 2017. The sample was drawn from the high schools and junior colleges registered with the District Educational Office, Hyderabad and Board of Intermediate Education, respectively. A total of 21 educational institutions (high schools and junior colleges) were selected randomly to draw the required samples of 465 students of classes IX, X, XI and XII. In order to maintain gender balance, adequate care was taken to obtain equal number of girls and boys.

Accordingly, a total of 536 students from the selected educational institutions were administered the questionnaire. Of them, 19 questionnaires were found as incomplete and the remaining 517 were found to be valid for analysis. These valid, filled-in questionnaires include 183 students of corporate/international institutions; 158 students of private institutions and 176 students of government institutions. The total of 517 subjects includes 253 boys and 264 girls. The pre-testing of the questionnaire was done before administering the same to the respondents.

\section{RESULTS and DISCUSSION}

Teenagers' responses in the study to a series of 15 questions were found to be diverse and varied based on their gender and families' socio-economic background (Figure 1). Teenagers are exposed to multiple media as they are not confined to a single kind of media to fulfil their information needs (Mekam et al., 2017). "Television, Internet, print media, and movies are mostly consumed by teenagers with not so much difference between them".

\section{Entertainment/Comedy: The most favourite}

Teenagers mostly craved for comedy in movies and in entertainment based programmes. Majority of adolescents, irrespective of gender and economic group, liked to watch humour coated content in TV and movies (Tables 1 and 2). Comedy in movies and entertainment programmes in television was found to be the most favourite as $73 \%$ of the represents liked.

In different types of television content (Table 1), movies and entertainment programmes were mostly watched by teenagers $(73 \%)$, followed by Sports and News (54\%). Nature and adventure related channels like 'Animal 


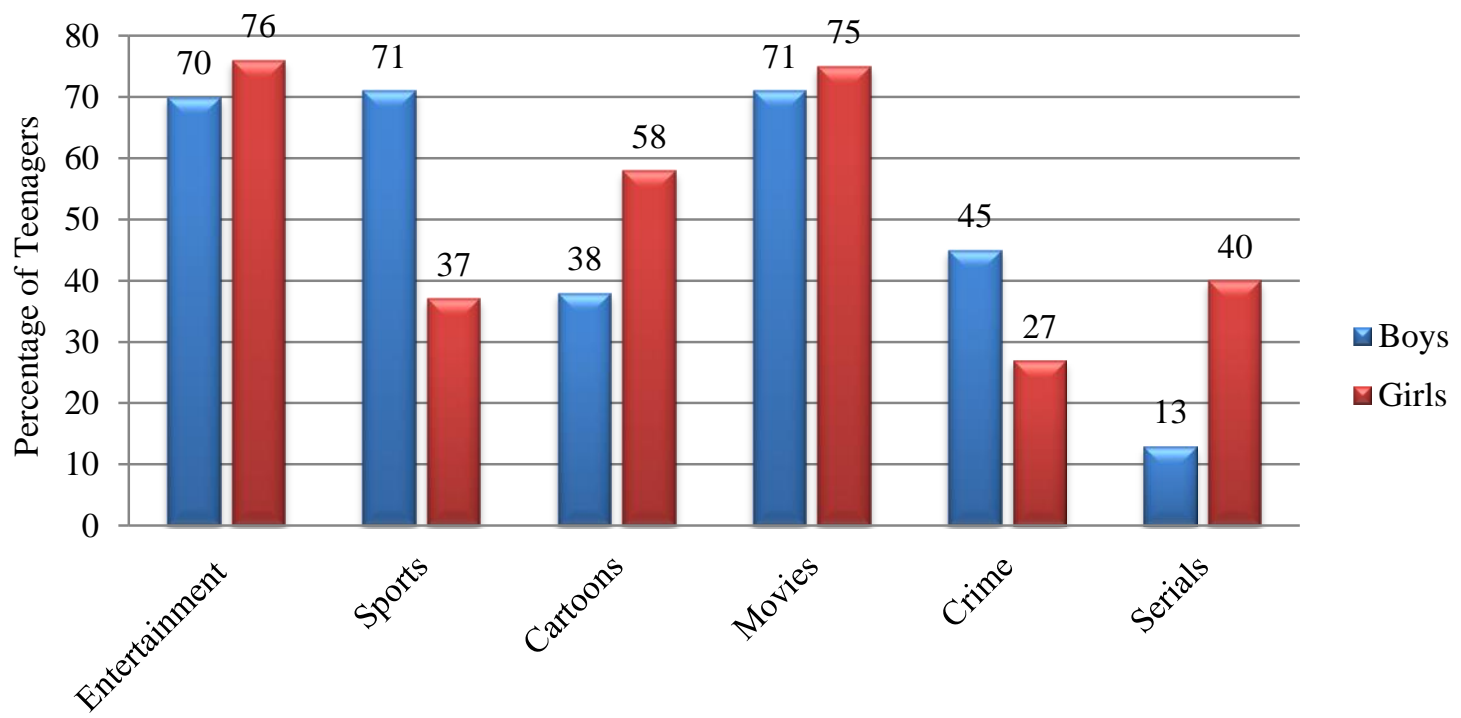

Figure 1. Comparison of teenagers' preferences in TV content.

Table 1. Television programme preferences of teenagers.

\begin{tabular}{|c|c|c|c|c|c|c|c|c|c|c|}
\hline \multirow[b]{2}{*}{ S/No. } & \multirow[b]{2}{*}{ Options } & \multirow[b]{2}{*}{$\begin{array}{c}\text { Total } \% \text { of } \\
\text { Boys + Girls } \\
{[N=517]}\end{array}$} & \multicolumn{4}{|c|}{ Boys (\%) } & \multicolumn{4}{|c|}{ Girls (\%) } \\
\hline & & & $\begin{array}{c}\text { Corp/ } \\
\text { Intl } \\
{[n=87]}\end{array}$ & $\begin{array}{c}\text { Pvt. } \\
{[n=81]}\end{array}$ & $\begin{array}{c}\text { Govt } \\
{[n=85]}\end{array}$ & $\begin{array}{c}\% \text { of } \\
\text { Boys } \\
{[n=253]}\end{array}$ & $\begin{array}{c}\text { Corp/ } \\
\text { Intl } \\
{[n=96]}\end{array}$ & $\begin{array}{c}\text { Pvt. } \\
{[n=77]}\end{array}$ & $\begin{array}{c}\text { Govt } \\
{[n=91]}\end{array}$ & $\begin{array}{c}\% \text { of } \\
\text { Girls } \\
{[n=264]}\end{array}$ \\
\hline 1. & Cartoons & 48 & 39 & 36 & 37 & 38 & 49 & 62 & 64 & 58 \\
\hline 2 & Sports & 54 & 69 & 70 & 68 & 71 & 47 & 27 & 35 & 37 \\
\hline 3 & Movies & 73 & 78 & 68 & 63 & 71 & 84 & 74 & 65 & 75 \\
\hline 4 & Entertainment/ Comedy & 73 & 78 & 67 & 62 & 70 & 79 & 69 & 80 & 76 \\
\hline 5 & Crime/Violence (e.g.WWF & 36 & 43 & 44 & 46 & 45 & 25 & 21 & 35 & 27 \\
\hline 6 & Animals/Forests (e.g. Discovery channel) & 52 & 63 & 51 & 55 & 58 & 46 & 43 & 49 & 46 \\
\hline 7 & Serials & 26.5 & 9 & 16 & 12 & 13 & 39 & 35 & 46 & 40 \\
\hline 8 & News & 54 & 53 & 52 & 54 & 54 & 44 & 41 & 77 & 54 \\
\hline 9 & Education related & 38.5 & 45 & 32 & 37 & 39 & 36 & 35 & 43 & 38 \\
\hline 10 & Advertisement & 19.5 & 25 & 21 & 13 & 20 & 21 & 15 & 21 & 19 \\
\hline 11 & Others & 8 & 5 & 10 & 10 & 8 & 6 & 12 & 6 & 8 \\
\hline
\end{tabular}

planet' and 'Discovery' were also popular among the teenagers $(52 \%)$; cartoon based channels were watched by $48 \%$ of the teenagers. Academic programmes on 'Doordarshan' were watched by $38.5 \%$ of teenagers. It was observed that, more than one-third of adolescents $(36 \%)$ preferred to watch violence-based content including WWF (World Wrestling Federation).

Overall, $75 \%$ of teenagers' preferred to watch television for movies or entertainment. In television programmes, preferences and tastes of girls were seen to differ from boys. Sports were most among $71 \%$ of boys, whereas only $37 \%$ girls preferred to watch them. $45 \%$ of boys showed an interest towards crime action based programme as compared to $27 \%$ of girls.
On the other hand, only $13 \%$ of male teenagers watched television serials (soap operas), but the percentage of girls $(40 \%)$ who had preferred to watch this content was three times more than the boys. Even cartoon programmes in television is mostly liked by girls $(58 \%)$ compared to boys (38\%).

In preferring television programmes, variation was evident even between teenagers' economic groups. Among both genders, teenagers of higher economic group were seen to watch more movies on television. $78 \%$ of the boys of high-income, $68 \%$ of middle-income and $63 \%$ low income group were seen to prefer movie based programme. On the other hand, $77 \%$ of girls from lower-economic group watched TV news as compared to 
Table 2. Types of movies teenagers watch.

\begin{tabular}{|c|c|c|c|c|c|c|c|c|c|c|}
\hline \multirow[b]{2}{*}{ S/No. } & \multirow[b]{2}{*}{ Options } & \multirow{2}{*}{$\begin{array}{c}\text { Total } \% \text { of Boys+ Girls } \\
{[\mathrm{N}=517]}\end{array}$} & \multicolumn{4}{|c|}{ Boys (\%) } & \multicolumn{4}{|c|}{ Girls (\%) } \\
\hline & & & $\begin{array}{l}\text { Corp/ Intl } \\
{[n=87]}\end{array}$ & $\begin{array}{c}\text { Pvt. } \\
{[n=81]}\end{array}$ & $\begin{array}{l}\text { Govt. } \\
{[n=85]}\end{array}$ & $\begin{array}{c}\% \text { of Boys } \\
{[n=253]}\end{array}$ & $\begin{array}{l}\text { Corp/ Intl } \\
{[n=96]}\end{array}$ & $\begin{array}{l}\text { Pvt. } \\
{[n=77]}\end{array}$ & $\begin{array}{l}\text { Govt. } \\
{[n=91]}\end{array}$ & $\begin{array}{c}\% \text { of Girls } \\
{[n=264]}\end{array}$ \\
\hline 1. & Action movies & 47.5 & 70 & 65 & 66 & 67 & 23 & 27 & 33 & 28 \\
\hline 2 & Horror movies & 57.5 & 57 & 59 & 49 & 55 & 45 & 74 & 64 & 60 \\
\hline 3 & Violent movies & 26.5 & 32 & 31 & 31 & 31 & 27 & 15 & 22 & 22 \\
\hline 4 & Comedy movies & 73 & 70 & 65 & 69 & 68 & 81 & 74 & 77 & 78 \\
\hline 5 & Romantic movies & 40 & 40 & 40 & 40 & 40 & 46 & 47 & 30 & 40 \\
\hline 6 & Historical movies & 39.5 & 47 & 30 & 38 & 38 & 33 & 47 & 44 & 41 \\
\hline 7 & Classical movies & 21 & 26 & 19 & 19 & 21 & 23 & 15 & 25 & 21 \\
\hline 8 & Others & 12 & 13 & 14 & 6 & 11 & 25 & 5 & 8 & 13 \\
\hline 9 & All types of movies & 20 & 18 & 20 & 24 & 21 & 25 & 13 & 19 & 19 \\
\hline
\end{tabular}

44 and $41 \%$ of other two economic (higher and middle economic strata) of the girls. Similar feature was observed among girls, as 84,74 and $65 \%$ of high, middle and low-income families respectively watched movies on television. In watching crime and violence based content, there was not much difference among percentage of boys of different economic groups, but percentage of girls $(35 \%)$ of low-income families was much higher than girls of high-income $(25 \%)$ and low-income $(21 \%)$ families.

\section{Movies: 'Action' to 'Horror'}

Apart from comedy based content, teenagers preferred to watch action and horror movies (Table 2). Particularly boys $(67 \%)$, irrespective of their economic group, preferred action movies as their favourite, whereas girls, of all the economic groups put together, only $28 \%$ had expressed their interest; also, girls $(60 \%)$ were found to be liking horror films more than boys (55\%).

Romantic and historical movies were also liked by high percentage of teenagers. Among males, $40 \%$ teenagers of all economic groups expressed their desire to view romantic movies. But, in females, it was significantly observed that, percentage of girls of only high-income $(46 \%)$ and middle-income $(47 \%)$ favouring romantic movies was not only more than girls $(30 \%)$ of low-income families, but even higher than boys.

Comedy movies topped the list among preferences of teenagers. A significant variation among boys and girls was observed among other genre of movies. Action movies were sought after by $67 \%$ boys, while only $28 \%$ of girls preferred to watch action films. Percentage of teenagers' preferring to watch historical movies also significantly varied between boys and girls of different economic groups. Of teenagers of high-income families, historical movies were favoured by $47 \%$ boys and only $33 \%$ girls. In middle-income families, these were favoured by only $30 \%$ boys and $47 \%$ girls. This gap got narrow in low-income families as $38 \%$ boys and $44 \%$ girls liked to watch historical movies.

\section{Print Media: Celebrities and sports}

Of all the content in newspapers or magazines, sportsrelated information and celebrities' gossips were mostly read by teenagers (Figure 2). $80 \%$ of boys read sports news and around $69 \%$ girls showed interest in reading about celebrities (Table 3). Educational pages in the newspapers/magazines were also popular among teenagers. Sports related content in print media was mostly read by boys ( $80 \%$ ) as compared to girls (48\%). On the other hand, news or gossips about celebrities was mostly read by girls (69\%) than boys $(58 \%)$.

Percentage of girls $(61 \%)$ was also high in searching newspapers for education related content as compared to boys $(51 \%)$. It is significantly observed that, among boys, $63 \%$ of high-income families favoured education related content in print media and only 42 and $47 \%$ boys of middle and low-income families respectively prioritized this. In contrast, among girls, $71 \%$ of lower-income families read education-related content in print media against only 55 and $56 \%$ of high and low-income families' girls respectively. This indicates reading taste of boys of higher-income strata and girls of lower-income strata are matching as far as education-related content in print media. With respect to the content of newspapers pertaining to political, business and feature articles, variation in percentages of boys and girls was significantly evident. Political content was mostly read by boys $(43 \%)$ in comparison to girls $(29 \%)$. Business page of newspapers was read by $30 \%$ of boys and the majority (38\%) belonged to high-income families. Girls (14\%) reading business related content in newspapers was not even half of the boys.

However, in contrast to boys, girls of low-income families $(24 \%)$ showed more interest in reading business related content as compared to the girls of other strata.

This again indicates matching of taste between boys of 


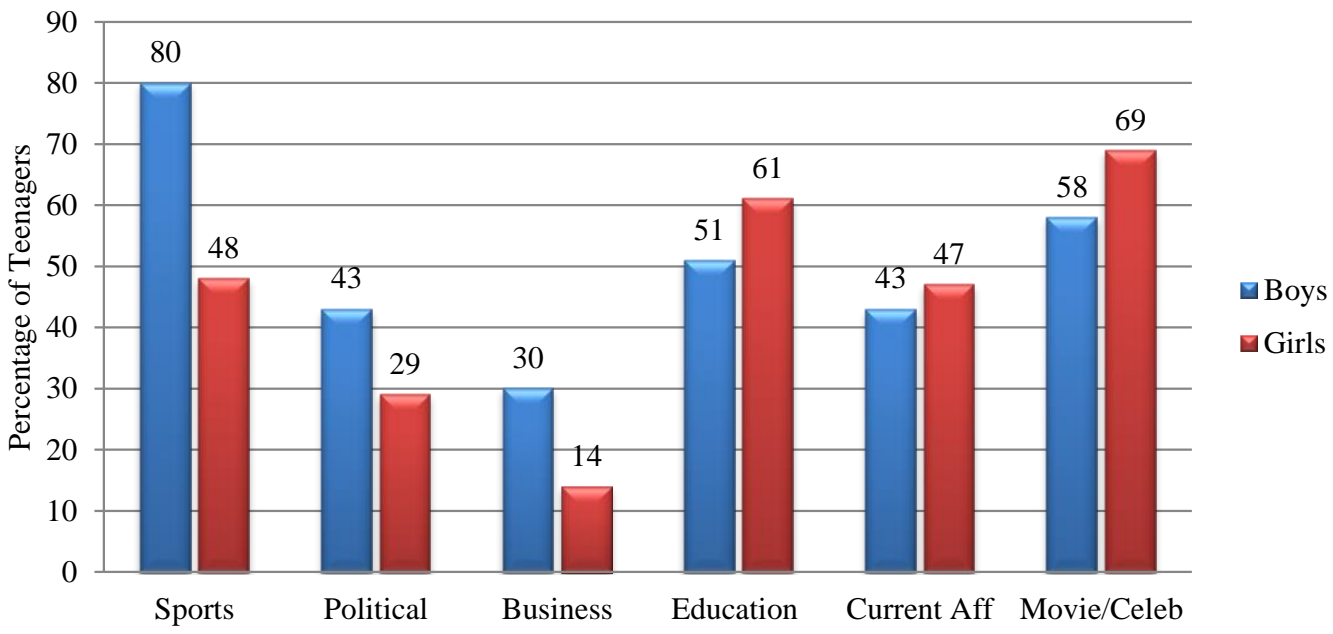

Figure 2. Teenagers' content choice in print media.

Table 3. Content of print media teenagers look for.

\begin{tabular}{|c|c|c|c|c|c|c|c|c|c|c|}
\hline \multirow[b]{2}{*}{ S/No. } & \multirow[b]{2}{*}{ Options } & \multirow{2}{*}{$\begin{array}{l}\text { Total \% of Boys } \\
+ \text { Girls [N=517] }\end{array}$} & \multicolumn{4}{|c|}{ Boys (\%) } & \multicolumn{4}{|c|}{ Girls (\%) } \\
\hline & & & $\begin{array}{c}\text { Corp/ Intl } \\
{[n=87]}\end{array}$ & $\begin{array}{c}\text { Pvt. } \\
{[n=81]}\end{array}$ & $\begin{array}{l}\text { Govt. } \\
{[n=85]}\end{array}$ & $\begin{array}{c}\% \text { of Boys } \\
{[n=253]}\end{array}$ & $\begin{array}{c}\text { Corp/ Intl } \\
{[n=96]}\end{array}$ & $\begin{array}{c}\text { Pvt. } \\
{[n=77]}\end{array}$ & $\begin{array}{l}\text { Govt. } \\
{[n=91]}\end{array}$ & $\begin{array}{c}\% \text { of Girls } \\
{[n=264]}\end{array}$ \\
\hline 1. & Sports related & 64 & 83 & 83 & 74 & 80 & 56 & 43 & 43 & 48 \\
\hline 2 & About Celebrities & 64 & 63 & 59 & 52 & 58 & 72 & 70 & 65 & 69 \\
\hline 3 & Political related & 36 & 47 & 41 & 41 & 43 & 22 & 28 & 36 & 29 \\
\hline 4 & Crime related & 45 & 47 & 38 & 48 & 45 & 34 & 45 & 57 & 45 \\
\hline 6 & Education related & 56 & 63 & 42 & 47 & 51 & 55 & 56 & 71 & 61 \\
\hline 7 & Women's page & 26.5 & 11 & 14 & 16 & 14 & 38 & 36 & 41 & 39 \\
\hline 8 & Business page & 22 & 38 & 27 & 26 & 30 & 4 & 13 & 24 & 14 \\
\hline 9 & Advertisements & 25.5 & 34 & 31 & 22 & 29 & 13 & 28 & 25 & 22 \\
\hline 10 & Stories/ Features & 40 & 34 & 26 & 26 & 29 & 52 & 47 & 53 & 51 \\
\hline
\end{tabular}

high-income families and girls of low-income families in reading business related content and liking educative content in newspapers.

Special stories and feature articles in newspapers and magazines were mostly favoured by girls (51\%) as compared to boys (29\%). One of the significant findings is that, advertisements in newspapers are mostly observed by $34 \%$ boys whereas only $13 \%$ girls of highincome families showed interest in them, indicating a broad gender variation in the same economic group. Dayto-day current affairs and news in print media was the favourite among the boys and girls of higher income families as compared to the lower income families.

\section{Use of Internet}

Teenagers were seen to browse Internet mostly to play games to socialise and for entertainment (Figure 3). Apart from Games, YouTube, Facebook, and chatting were most frequently visited websites by teenagers. Education related websites were also equally popular among the teenagers. Significant percentage of teenagers browsed Internet for health-related content. It is significantly observed that, 'digital divide' exist between boys and girls and between different economic backgrounds of teenagers as well.

YouTube visuals were mostly watched by boys (62\%) than girls (47\%). Even among boys and girls, variations in percentages appear between different economic strata (Table 4). In high-income families, a whopping $78 \%$ teenage boys browse for visuals in YouTube as against only $66 \%$ girls. In middle-income families, $60 \%$ boys and $54 \%$ girls view YouTube. These percentages in lowincome families were low as only $48 \%$ boys and only22\% of girls access YouTube. This feature is not similar 


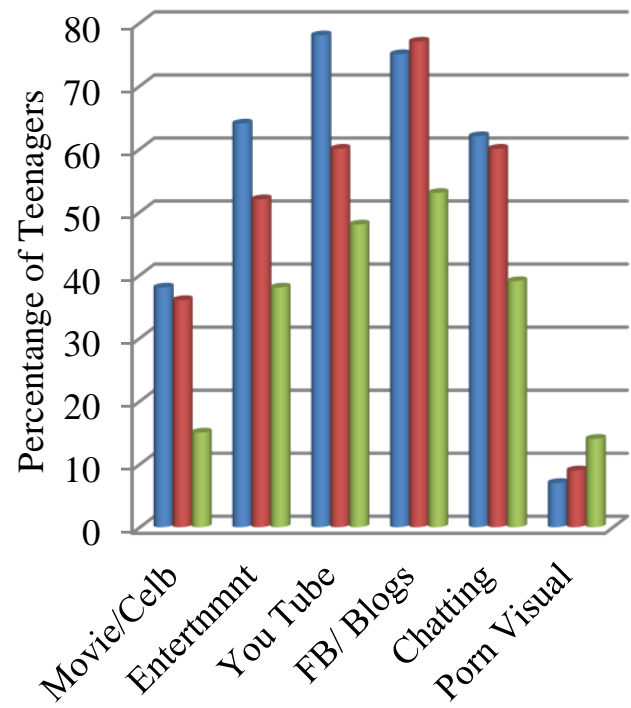

(a)

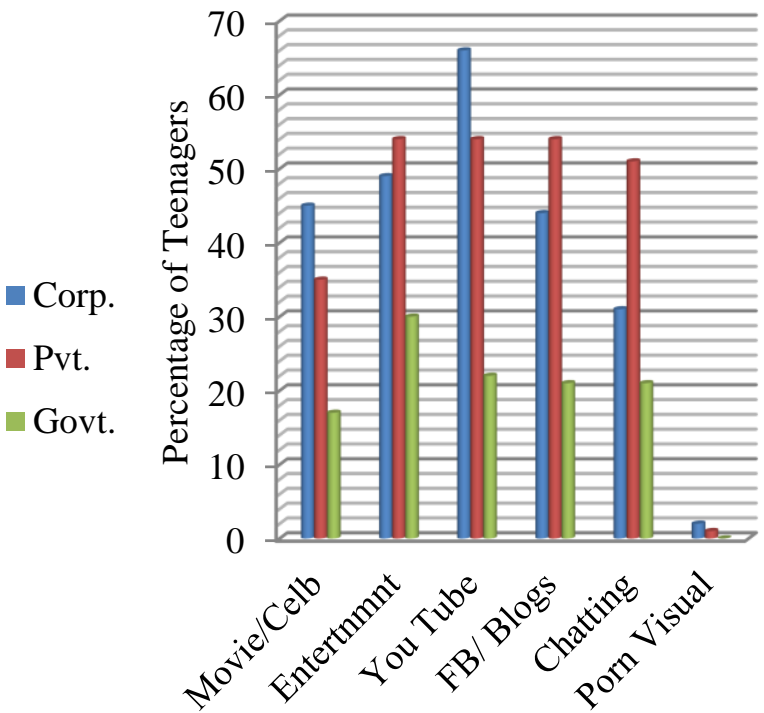

(b)
- Corp.

- Pvt.

Govt.

Figure 3. Percentage of teenagers (a) boys and (b) girls browsing various content on internet.

Table 4. Type of content teenagers browse on internet.

\begin{tabular}{|c|c|c|c|c|c|c|c|c|c|c|}
\hline \multirow[b]{2}{*}{ S/No. } & \multirow[b]{2}{*}{ Options } & \multirow{2}{*}{$\begin{array}{c}\text { Total } \% \text { of } \\
\text { Boys + Girls } \\
{[\mathrm{N}=517]}\end{array}$} & \multicolumn{4}{|c|}{ Boys (\%) } & \multicolumn{4}{|c|}{ Girls (\%) } \\
\hline & & & $\begin{array}{c}\text { Corp/ Intl } \\
{[n=87]}\end{array}$ & $\begin{array}{c}\text { Pvt. } \\
{[n=81]}\end{array}$ & $\begin{array}{c}\text { Govt. } \\
{[n=85]}\end{array}$ & $\begin{array}{c}\% \text { of Boys } \\
{[n=253]}\end{array}$ & $\begin{array}{c}\text { Corp/ Intl } \\
{[n=96]}\end{array}$ & $\begin{array}{c}\text { Pvt. } \\
{[n=77]}\end{array}$ & $\begin{array}{l}\text { Govt. } \\
{[n=91]}\end{array}$ & $\begin{array}{c}\% \text { of Girls } \\
{[n=264]}\end{array}$ \\
\hline 2 & Film actors/ Celebrities & 31 & 38 & 36 & 15 & 45 & 35 & 17 & 32 & 45 \\
\hline 3 & Entertainment & 47.5 & 64 & 52 & 38 & 49 & 54 & 30 & 44 & 49 \\
\hline 4 & You Tube & 54.5 & 78 & 60 & 48 & 66 & 54 & 22 & 47 & 66 \\
\hline 6 & Chatting & 43.5 & 62 & 60 & 39 & 31 & 51 & 21 & 33 & 31 \\
\hline 7 & Movies & 48 & 54 & 49 & 44 & 68 & 44 & 27 & 47 & 68 \\
\hline 8 & Games & 56 & 63 & 67 & 57 & 48 & 57 & 45 & 50 & 48 \\
\hline 9 & Education related & 46 & 51 & 48 & 41 & 51 & 41 & 43 & 45 & 51 \\
\hline 10 & Health related & 25.5 & 30 & 16 & 23 & 23 & 38 & 24 & 28 & 23 \\
\hline 15 & Others & 8 & 9 & 9 & 9 & 10 & 6 & 4 & 7 & 10 \\
\hline
\end{tabular}

in using social media, like Facebook, where teenagers of middle-income families accessed more as compared to high and low-income families.

In middle-income families, $77 \%$ boys and $54 \%$ girls spent time on social media (Facebook) followed by highincome families where $75 \%$ boys and $44 \%$ girls were active on Facebook and in low-income families, 53\% boys and $21 \%$ girls had have Facebook accounts.

It is significantly observed that, social networking sites like Facebook and YouTube were mostly visited by male teenagers. Digital divide is observed between male and female teenagers. This observation strengthens a finding of a global study by GSMA (Global System for Mobile Communications). According to GSMA's 2020 mobile gender gap report, only $21 \%$ of women in India are mobile internet users, while $42 \%$ of men have access.

The report says that while $79 \%$ of men own a mobile phone in the country, the number for women is $63 \%$.

A startling revelation of this study was that, $10 \%$ of boys reported to be browsing porn sites on Internet. This 
Table 5. Kind of health related information teenagers like to know.

\begin{tabular}{|c|c|c|c|c|c|c|c|c|c|c|}
\hline \multirow[b]{2}{*}{ S/No. } & \multirow[b]{2}{*}{ Options } & \multirow[b]{2}{*}{$\begin{array}{c}\text { Total } \% \text { of } \\
\text { Boys + Girls } \\
{[N=517]}\end{array}$} & \multicolumn{4}{|c|}{ Boys (\%) } & \multicolumn{4}{|c|}{ Girls (\%) } \\
\hline & & & $\begin{array}{c}\text { Corp/ } \\
\text { Intl } \\
{[n=87]}\end{array}$ & $\begin{array}{c}\text { Pvt. } \\
{[n=81]}\end{array}$ & $\begin{array}{c}\text { Govt. } \\
{[n=85]}\end{array}$ & $\begin{array}{c}\% \text { of } \\
\text { Boys } \\
{[n=253]}\end{array}$ & $\begin{array}{c}\text { Corp/ } \\
\text { Intl } \\
{[n=96]}\end{array}$ & $\begin{array}{c}\text { Pvt. } \\
{[n=77]}\end{array}$ & $\begin{array}{l}\text { Govt. } \\
{[n=91]}\end{array}$ & $\begin{array}{c}\% \text { of } \\
\text { Girls } \\
{[n=264]}\end{array}$ \\
\hline 1. & About cure/ Prevention of diseases & 56 & 54 & 54 & 47 & 52 & 73 & 58 & 48 & 60 \\
\hline 2 & Nutrition and healthy food items & 68 & 61 & 65 & 56 & 61 & 70 & 73 & 83 & 75 \\
\hline 3 & About overweight problem & 30 & 33 & 22 & 19 & 25 & 49 & 34 & 19 & 34 \\
\hline 4 & About underweight problem & 28 & 36 & 32 & 26 & 31 & 23 & 23 & 26 & 24 \\
\hline 5 & Improvement of skin colour & 41.5 & 41 & 42 & 38 & 40 & 44 & 39 & 45 & 43 \\
\hline 6 & Beauty tips/ cure pimples & 41 & 30 & 36 & 34 & 33 & 49 & 49 & 49 & 49 \\
\hline 7 & About increase of body height & 38.5 & 45 & 31 & 46 & 41 & 35 & 36 & 37 & 36 \\
\hline 8 & Tips to become slim or 'size zero' & 19 & 22 & 12 & 14 & 16 & 29 & 23 & 14 & 22 \\
\hline 9 & About achieving six-pack body & 27 & 52 & 44 & 50 & 49 & 4 & 6 & 3 & 4 \\
\hline 10 & Others & 4.5 & 3 & 4 & 5 & 4 & 4 & 8 & 3 & 5 \\
\hline
\end{tabular}

trend further confirms findings of a similar study by Andrew and Victoria (2018). The data of European Union in that study showed the percentage of boys reported watching more sexual content online increased monotonically with age from a low of $7.5 \%$ (among 11 year olds) to a high of $35.4 \%$ (16-year olds).

Among girls, only $1 \%$ stated that they visited porn sites. On the other hand, it was startling to find out that the boys of lower income group were seen to be browsing porn sites more than those belonging to other groups.

Of all the contents of Internet, porn was the only content where boys of poor families (14\%) got more in comparison to boys of $(7 \%)$ rich and boys of $(9 \%)$ middleclass families. This may be due to lack of proper parental guidance or peer pressure among them and also indicates the misuse of Internet by these boys.

It is significantly observed that, for whatever content, usage of Internet is less in teenagers of poor families. It is seen as low in boys and very low in girls of this stratum. But, of all (15) kinds of contents in Internet, girls of poor families browsed mostly for Education related (43\%) in addition to games (45\%). This indicates that, girls of loweconomic families accessed Internet as it is mandatory for their educational purpose. For remaining, the percentage of girls of poor families accessing Internet was much below the $30 \%$, which showed up the glaring 'digital divide' between girls of low-income families and middle and high-income families.

The digital divide was not found to be so different even among boys of low-income families. Though, the percentage of boys of poor families was higher than the girls of same economic group, it was far less as compared to boys of rich and middle-class families.

Digital divide is less between teenagers of rich families and middle-class families, when compared with teenagers of poor families. For example, among boys, content related to Sports, Facebook/blogs, Games, and Bookings/ purchases websites are visited mostly by boys of middle- class families, compared to boys of rich families. Similarly, among girls, content related to Entertainment, Health, Advertisements, and websites of Games and Chatting were mostly browsed by girls of middle-income families' in comparison to girls of rich families. But, overall, percentages of boys and girls of high-income families using internet is much higher than the teenagers of middle and low-income families.

\section{Nutrition tops among health-related topics}

Of all kinds of health topics, majority of the teenagers $(68 \%)$, irrespective of gender and economic group, liked to know more about healthy and nutritious food items (Table 5). More number of girls $(75 \%)$ showed interest in healthy eatables as items demand more, compared to boys $(61 \%)$. Information on 'prevention and cure of diseases' was the second most searched topic (56\%) among teenagers. Usual teenage obsessions like 'how to improve skin colour', 'cure pimples', 'increase body height' are also significant topics that teenagers were keen to know under health-related topics.

Among the three strata, girls belonging to poor families stands at a whopping $83 \%$ who were eager to know about nutritious food items to remain fit and healthy. This percentage was much higher than even the girls of middle-class $(73 \%)$ and rich-class $(70 \%)$ families. This feature appears reverse among the males where, percentage of boys of poor families was less (56\%) as compared to boys of middle-class (65\%) and rich-class $(61 \%)$ families in seeking information about nutrition food items.

Girls $(60 \%)$ were also more eager than boys $(52 \%)$ to know about cure/prevention of diseases. In rich-class families, $73 \%$ girls as against only $54 \%$ boys were very interested to know about prevention and cure of diseases. In middle-class families, this percentage stands 
Table 6. On health and nutrition, the primary sources of information for teenagers.

\begin{tabular}{|c|c|c|c|c|c|c|c|c|c|c|}
\hline \multirow[b]{2}{*}{ S/No. } & \multirow[b]{2}{*}{ Options } & \multirow[b]{2}{*}{$\begin{array}{l}\text { Total \% of Boys } \\
+ \text { Girls [N=517] }\end{array}$} & \multicolumn{4}{|c|}{ Boys (\%) } & \multicolumn{4}{|c|}{ Girls (\%) } \\
\hline & & & $\begin{array}{c}\text { Corp/ Intl } \\
{[\mathrm{n}=87]}\end{array}$ & $\begin{array}{l}\text { Pvt. } \\
{[\mathrm{n}=81]}\end{array}$ & $\begin{array}{l}\text { Govt. } \\
{[\mathrm{n}=85]}\end{array}$ & $\begin{array}{c}\% \text { of Boys } \\
{[n=253]}\end{array}$ & $\begin{array}{c}\text { Corp/ Intl } \\
{[\mathrm{n}=96]}\end{array}$ & $\begin{array}{l}\text { Pvt. } \\
{[\mathrm{n}=77]}\end{array}$ & $\begin{array}{l}\text { Govt. } \\
{[n=91]}\end{array}$ & $\begin{array}{c}\% \text { of Girls } \\
{[n=264]}\end{array}$ \\
\hline 1. & Internet & 60 & 70 & 69 & 48 & 62 & 71 & 67 & 33 & 57 \\
\hline 2 & Newspaper/ Magazine & 53 & 45 & 57 & 40 & 47 & 61 & 52 & 63 & 59 \\
\hline 3 & Television & 37.5 & 27 & 42 & 38 & 35 & 42 & 28 & 47 & 40 \\
\hline 4 & Parents/ Relatives & 65 & 53 & 60 & 62 & 58 & 74 & 64 & 78 & 72 \\
\hline 5 & Friends & 32.5 & 31 & 37 & 29 & 32 & 30 & 28 & 41 & 33 \\
\hline 6 & Other & 6 & 3 & 5 & 10 & 6 & 4 & 5 & 10 & 6 \\
\hline
\end{tabular}

as $58 \%$ girls and $54 \%$ boys and in poor families $48 \%$ girls and $47 \%$ boys love to know about diseases prevention/ cure in detail.

A good number of percentages of teenagers' (41.5\%) were willing to seek health tips for 'improvement of skin colour'. Of them, again girls (45\%) of poor-families were more as compared to others. In contrast, boys $(38 \%)$ of poor-families are less in comparison with boys of rich $(41 \%)$ and middle-class (42\%) families in seeking healthy tips for improvement of skin colour. Pimples on face were major concern of beauty for most of the teenagers. To get rid of this problem, almost $50 \%$ of girls and one-third of boys were enthusiastic to seek information from mass media.

Teenage boys (41\%) are more eager than girls (36\%) to seek information on 'increasing height. However, it was significantly observed that, boys of middle-class families were only $31 \%$ as against boys of rich (45\%) and poor $(46 \%)$ families. Similar trend appears on the topic of 'how to achieve six pack bodies', which is a current obsession among the youth. On this topic, only $44 \%$ boys of middleclass families were interested as against 52 and $50 \%$ boys of rich and poor families respectively. Of all the female teenagers, topic on 'tips to become slim or sizezero' created more interest among girls of rich-families $(29 \%)$ in comparison with girls $(23 \%)$ of middle-class and girls $(14 \%)$ of poor families.

It was also significant to note that, information on 'overweight problem' is mostly sought by teenagers of highincome families, particularly by girls. In rich families, $49 \%$ girls and $33 \%$ boys; in middle-class families $34 \%$ girls and $22 \%$ boys was interested in seeking health tips to get rid of over-weight problem. This percentage in teenagers of poor-class families was only $19 \%$ in both genders.

This clearly indicates that over-weight or obesity was being perceived as a problem of adolescent age itself among the rich and middle-class families as compared to poor. This finding corroborates with outcome of an earlier study (Mekam et al., 2011) on how the framing of obesity in popular media matters appearance of individuals. However, on the topic of 'under-weight' problem, girls of poor families $(26 \%)$ were more interested as compared to girls of rich among $(23 \%)$ girls of middle class families
(23\%). Among males, demand for this topic was more among boys of rich-class families (36\%) and boys of middle class families $(32 \%)$ in comparison with boys of poor families $(26 \%)$. This indirectly strengthens the results of many studies revealing gender-bias in feeding against females in poor families.

\section{Parents and Internet are primary sources}

Parents were serving as primary source of health and nutrition information for girls. However, for majority of boys, Internet was the most accessible source for health and nutrition information (Table 6 ). $72 \%$ of girls preferred to approach their parents rather than any other media for any health and nutrition-related query. After parents, girls mostly $(59 \%)$ rely on print media and Internet as the third option (57\%) to know about health and nutrition-related matter.

But for boys, Internet (62\%) was the primary source and parents $(58 \%)$ were secondary source followed by print media $(47 \%)$ for health and nutrition-related information. Television also served as a source of health and nutrition information for more than one-third of boys or girls. Little less than one-third boys/girls exchanged health and nutrition information with their friends.

The number of girls preferring to approach parents for health and nutrition information was more in poor families $(78 \%)$ as compared to girls of rich $(74 \%)$ and girls of middle-class $(64 \%)$ families. Same is the case with boys who preferred to approach parents for health and nutrition information as, boys of poor families $(62 \%)$ are more compared to boys of rich (53\%) and boys of middleclass $(60 \%)$ families. This feature indirectly indicates the levels of family bonding of children and parents based on their families' economic background.

Teenagers' tendency to access Internet for health and nutrition information again indicates digital divide between boys and girls and economic status of their respective families as well. About $70 \%$ of boys and girls preferred to access Internet for health and nutrition information in high-income families. In middle-income families, it was $69 \%$ among boys and $67 \%$ among girls. In poor-income 
Table 7. Pattern of leisure time teenagers spend.

\begin{tabular}{|c|c|c|c|c|c|c|c|c|c|c|c|c|c|}
\hline \multirow[b]{2}{*}{ S/No. } & \multirow[b]{2}{*}{ Options } & \multirow{2}{*}{$\begin{array}{c}\text { Total } \% \text { of Boys + } \\
\text { Girls [N=517] }\end{array}$} & \multirow[b]{2}{*}{ Rank } & \multicolumn{4}{|c|}{ Boys (\%) } & \multirow[b]{2}{*}{ Rank } & \multicolumn{4}{|c|}{ Girls (\%) } & \multirow[b]{2}{*}{ Rank } \\
\hline & & & & $\begin{array}{c}\text { Corp/ Intl } \\
{[n=87]}\end{array}$ & $\begin{array}{c}\text { Pvt. } \\
{[n=81]}\end{array}$ & $\begin{array}{l}\text { Govt. } \\
{[n=85]}\end{array}$ & $\begin{array}{c}\% \text { of Boys } \\
{[n=253]}\end{array}$ & & $\begin{array}{c}\text { Corp/ Intl } \\
{[n=96]}\end{array}$ & $\begin{array}{c}\text { Pvt. } \\
{[n=77]}\end{array}$ & $\begin{array}{c}\text { Govt. } \\
{[n=91]}\end{array}$ & $\begin{array}{c}\% \text { of Girls } \\
{[n=264]}\end{array}$ & \\
\hline 1. & Play indoor games & 51 & 7 & 46 & 49 & 43 & 46 & 57 & 43 & 63 & 55 & 5 & 57 \\
\hline 2 & Play outdoor games & 59 & 3 & 62 & 76 & 62 & 67 & 64 & 41 & 45 & 51 & 6 & 64 \\
\hline 3 & Watch movies & 71.5 & 1 & 71 & 76 & 60 & 69 & 83 & 64 & 72 & 74 & 1 & 83 \\
\hline 4 & Watch television & 61.5 & 2 & 60 & 58 & 58 & 58 & 74 & 61 & 59 & 65 & 2 & 74 \\
\hline 5 & Internet browsing & 51.5 & 6 & 61 & 57 & 49 & 56 & 58 & 61 & 24 & 47 & 7 & 58 \\
\hline 6 & Face book/ Chatting & 50.5 & 8 & 52 & 75 & 58 & 61 & 43 & 56 & 25 & 40 & 9 & 43 \\
\hline 7 & You tube & 44 & 9 & 54 & 53 & 34 & 47 & 54 & 54 & 16 & 41 & 8 & 54 \\
\hline 8 & Reading books & 52 & 5 & 42 & 44 & 39 & 42 & 63 & 51 & 71 & 62 & 3 & 63 \\
\hline 9 & Listen radio & 22 & 11 & 14 & 22 & 10 & 15 & 29 & 18 & 38 & 29 & 10 & 29 \\
\hline 10 & Chit chat with friends & 53.5 & 4 & 50 & 53 & 38 & 47 & 63 & 56 & 59 & 60 & 4 & 63 \\
\hline 11 & Involve in hobbies & 42 & 10 & 39 & 37 & 35 & 37 & 53 & 47 & 42 & 47 & 7 & 53 \\
\hline 12 & Other & 13.5 & 12 & 14 & 17 & 14 & 15 & 12 & 14 & 11 & 12 & 11 & 12 \\
\hline
\end{tabular}

families, it was $48 \%$ among boys and only $33 \%$ among girls. It is significantly observed that teenage girls of poor families (33\%) were not even half the percentage of girls of rich $(71 \%)$ or middle-class (67\%) families in accessing Internet for health and nutrition related information.

Teenagers' preference for print media (newspapers/magazines) as source of health and nutrition information was high among girls of rich $(61 \%)$ and poor $(63 \%)$ families, and low in boys of rich $(45 \%)$ and poor $(40 \%)$ families. But, television was not considered as a uniform source for health and nutrition information by teenagers. Percentage of teenagers was seen as significantly unmatched between genders and also between economic conditions of their respective families. For example, in rich families, $27 \%$ of boys and $42 \%$ of girls; in middle-class families, $42 \%$ of boys and $28 \%$ of girls; and in poor families, $38 \%$ of boys and $47 \%$ of girls accessed television for health and nutrition related information. Sharing health and nutrition-related information with friends also varied in teenagers of middle and low-income families. Approaching friends for health information was almost similar in boys (31\%) and girls (31\%) of rich families; whereas in middle-class families, it was $37 \%$ among boys and $28 \%$ among girls; and in low-income families, it was $29 \%$ among boys and $41 \%$ among girls.

\section{Leisure-time: Boys on Facebook, Girls read books}

Teenagers, particularly students, usually have plenty of leisure time especially during vacation and weekends. Leisure-time activity also plays a role in one's diet and health-related behaviour. Since teenagers possess considerable amount of leisure-time, this study made an attempt to elicit information about their leisure-time activities.

Watching movies during leisure-time appears as the top-most activity for majority teenagers $(71.5 \%)$. Of them, boys comprised $69 \%$ and girls account for $74 \%$ (Table 7). For both genders put together, other leisure-activities were ranked as follows: Watch television (61.5\%), play outdoor games $(59 \%)$, spend time with friends $(53.5 \%)$, book reading $(52 \%)$, browsing Internet $(51.5 \%)$, playing indoor games $(51 \%)$, being on Facebook or on-line chatting $(50.5 \%)$, watch YouTube visuals (44\%), enjoying in hobbies (42\%), listening to radio $(22 \%)$.

However, on spending leisure time, many variations were observed between boys and girls and also between different strata of the same gender. Except for watching movies, there was no match at all between boys and girls in according priorities for all other kinds of leisure home activities. After movies, majority of boys preferred to play outdoor games $(67 \%)$ and be on Facebook or on-line chatting $(61 \%)$, whereas, in the case of girls, after movies, they prefer to watch television 
(65\%) and read books (62\%) to consume leisure-time.

Playing outdoor games during the leisure time is more in boys of middle-income families (76\%), compared to boys of high-income (62\%) and boys of low-income $(62 \%)$ families. Similarly, spending time on Facebook and on-line chatting is also more in male teenagers of middleincome families $(75 \%)$, compared to high income (52\%), and low-income families (58\%).

On the other hand, Internet browsing and YouTube visuals are seen mostly by boys of high-income families $(61 \%$ and $54 \%)$ followed by boys of middle $(57 \%$ and $53 \%$ ) and low-income (49\% and $34 \%$ ) families. This again indicate 'digital divide' between economic groups of the teenagers and strengthens earlier finding of this study.

In ranking different kinds of leisure-time activities based on the majority of boys and girls, book reading stands at $3^{\text {rd }}$ place for girls and at $8^{\text {th }}$ place for boys. Of all the female teenagers ranked for time spent on reading books, the percentage of girls belonging to low-income families $(71 \%)$ was very high as compared to girls of high-income $(63 \%)$ and girls of middle-income families $(51 \%)$. In contrast, the percentage of boys of low-income families for book reading was less $(39 \%)$ as compared to boys of high-income (42\%) and middle-income families (44\%).

Similar contrasting observations between boys and girls were observed in other leisure activities too. For example, girls $(55 \%)$ played more indoor games during leisure compared to boys (46\%), whereas boys (67\%) played more outdoor games as to girls (51\%). Percentage of girls who watched movies (74\%) and television (65\%) was more compared to boys (69 and $58 \%$ respectively), Whereas, the percentage of boys browsing internet (56\%), being on Facebook/on-line chatting (61\%) and watching YouTube (47\%) was more as compared to girls (47, 40 and $41 \%$, respectively).

Girls were seen to be spending more time with friends $(60 \%)$ and pursuing hobbies (47\%) as compared to boys (47 and $37 \%$ respectively). Also, the time spent listening to radio was almost double (29\%) in girls as compare to boys (15\%). All these observations point to significant fact that girls mostly get involved in home-based or indoor activity whereas, boys mostly get involved in outdoor activities, in addition to usages of Internet including Facebook and YouTube.

\section{Conclusions}

Media plays an important role in social development. Teenagers are considered as future of the society and the progress of any nation is largely dependent on the perspective and awareness levels of teenagers shaped during their adolescent age. In today's world, the ubiquitous presence of media is bound to leave impressions on the minds of tender-aged civilians. Keeping this in view, this study throws insights on how and to what extent the media content is being used by adolescents, in addition to other sources. Parents and Internet are serving as primary source of health and nutrition information for majority of teenagers. Parents for girls and Internet for boys are the most accessible source for health and nutrition information. Girls mostly rely on parents than on print media. Internet is only a third option for them to know about health and nutrition-related matter. It is significantly observed that, for whatever content, usage of Internet is less in teenagers of poor families. It is seen as low in boys and very low in girls of this stratum. But, of all (15) kinds of contents in Internet, girls of poor families browse mostly for Education related $(43 \%)$ in addition to games (45\%). This indicates that, girls of low-economic families access Internet as it is mandatory for their education purpose. For the remaining, percentage of girls of poor families accessing Internet is much below the $30 \%$, which manifests the glaring 'digital divide' between girls of low-income families and middle and high-income families. The digital divide is not so different even among boys of low-income families. Though, the percentage of boys of poor families is higher than the girls of same economic group, it is far less when compared to boys of rich and middle-class families. Overall, $10 \%$ of boys browse porn sites in Internet and only $1 \%$ of girls visit porn sites. One startling revelation about boys of poor families is that, in watching porn visuals, their percentage is more compared to boys of rich and middle-class families. Of all the contents of Internet, this (porn visuals) is the only content where boys of poor families (14\%) appear more in comparison to boys of rich and boys of middle-class families. This clearly indicates the misuse of Internet by boys of poor families. Of all kinds of health topics, majority of teenagers, irrespective of gender and economic group, like to know more and more information about healthy and nutritious food items. Girls belonging to poor families are very eager to know about nutritious food items to remain fit and healthy. It is significantly observed that, information on 'over-weight problem' is mostly sought by teenagers of high-income families, particularly by girls. However, on the topic of 'under-weight' problem, girls of poor families are more interested when compared to girls of rich and middle class families.

\section{RECOMMENDATIONS AND SUGGESTIONS}

Findings of this study recommends that parents, the media, health practitioners and policy makers, among others, look into ways to increase the benefits and reduce the harm that media can have on the development of children and adolescents. This study offers suggestion for further research that could facilitate the use of mass media for health promotion and disease prevention.

\section{CONFLICT OF INTERESTS}

The authors have not declared any conflict of interests. 


\section{ACKNOWLEDGEMENTS}

The authors thank Dr. Hemalatha Director, Indian Council of Medical Research, National Institute of Nutrition (ICMR-NIN), Hyderabad, India.

\section{REFERENCES}

American Academy of Paediatrics (2013). Children, adolescents, and the media.policy statement. Journal of Pediatrics 132:958-61.

American College of Obstetricians and Gynecologists (2016). Concerns regarding social media and health issues in adolescents and young adults. Committee Opinion No. 653. Obstetrics and Gynecology 127:62-65.

Andrew KP, Victoria N (2018). Internet Filtering and Adolescent Exposure to Online Sexual Material. Cyberpsychology, behavior and social networking 21(7):405-410. https://doi.org/10.1089/cyber.2017.0466.

Blum RW, Bastos FB, Kabiru CW, Le LC (2012). Adolescent health in the 21 st century. Lancet 379:1567.

Brown JD, Engle KL (2009). X-rated: sexual attitudes and behaviors associated with U.S. early adolescents' exposure to sexually explicit media. Communication Research 36:129-151.

Buckingham D, Bragg S (2004). Young people, sex and the media: The facts of life. Palgrave Macmillan Press.

McQuail D (2005). McQuail's Mass Communication Theory 5:406. http://docshare04.docshare.tips/files/28943/289430369.pdf.

Farrelly MC, Nonnemaker J, Davi KC, Hussain A (2009). The influence of the national truth campaign on smoking initiation. American Journal of Preventive Medicine 36(5):379-384.

Gunther, Albert C, Bolt D, Dina LG, Janice B, Liebhart L, Dillard JP (2006). Presumed influence on peer norms: How mass media indirectly affect adolescent smoking. Journal of Communication 56 (1):52-68

Gupta PC, Ray CS, Narake SS, Palipudi KM, Sinha DN, Asma S, Blutcher-Nelson G (2012). Profile of dual tobacco users in India: An analysis from Global Adult Tobacco Survey, 2009-10". Indian journal of cancer 49(4):393.

Hallin DC, Mancini P (2011). Comparing media systems beyond the Western world. Cambridge University Press.

Hanewinkel R, Isensee B, Sargent JD, Morgenstern M (2010). Cigarette advertising and adolescent smoking. American Journal of Preventive Medicine 38(4):359-66.

He M, Tucker P, Gilliland J, Irwin JD, Larsen K, Hess P (2012). The influence of local food environments on adolescents' food purchasing behaviors. International Journal of Environmental Research and Public Health 9(4):1458-1471.

Henry J (2001). How young people use the Internet for health information. Menlo Park (CA), Generation Rx.com. Kaiser Family Foundation.

Institute of Medicine and National Research Council (2014). Investing in the health and well-being of young adults. Washington, DC: The National Academies Press.

O'Keeffe GS, Clarke-Pearson K (2011). The impact of social media on children, adolescents, and families. Journal of Paediatrics 127(4):800-804.

Keinan A, Kivetz R (2011). Productivity orientation and the consumption of collectable experiences. Journal of Consumer Research 37(6):935-950.

Kelly Y, Zilanawala A, Booker C, Sacker A (2018). Social Media Use and Adolescent Mental Health: Findings from the UK Millennium Cohort Study. E Clinical Medicine 6:59-68. https://doi.org/10.1016/j.eclinm.2018.12.005
Lovato C, Watts A, Stead LF (2011). Impact of tobacco advertising and promotion on increasing adolescent smoking behaviours. Cochrane Database of Systematic Reviews 10. CD003439. DOI: 10.1002/14651858.CD003439

Luscombe B (2016). Porn and the threat to virility. Time 187:40-47.

McAfee T, Davis KC, Alexander J, Pechacek RL, Bunnell R (2013). Effect of the first federally funded US antismoking national media campaign. The Lancet 382(9909):2003-2011

Mead D (2016). The risks young people face as porn consumers. Addicta-The Turkish Journal on Addictions 3:387-400.

Mekam M, Rao DR (2011). A matter of looks: The framing of obesity in popular Indian daily newspapers. Journal of US-China medical science 8(1):30-34.

Mekam M, Vijayapushpam T, Rao SF (2014). A current appraisal of health and nutrition related claims in Indian children' television food advertisements. Journal of Social Science Studies 1(2):125-135.

Mekam M (2016). "Influence of Mass Media on Teenagers Diet and Health Related Behaviour." http://hdl.handle.net/10603/176723

Mekam M, Narender K, Balakrishna N, Rao DR (2017). "Media viewing habits of teenagers". International Journal of Research in Management, Economics and Commerce 7(2):1-9.

Moreno M, Standiford M, Cody P (2018). Social media and adolescent health. Current Paediatric Report 6(2):132-138.

NFHS-3 Report (2005-06). National Family Health Survey. https://dhsprogram.com/pubs/pdf/SR128/SR128_updated_09-222015.pdf

Odden $L$ (2014). What is content? Learn from $40+$ definitions. Top Rank Online Marketing.Retrieved on $12^{\text {th }}$ December 2014.

Sabina C, Wolak J, Finkelhor D (2008). The nature and dynamics of internet pornography exposure for youth. Cyber psychol Behavior 11: 691-693.

Sawyer SM, Bearinger LH, Blakemore SJ, Dick B, Ezeh A, Patton GC (2012). Adolescence: A foundation for future health. Lancet 379:1630-1640.

Springate J, Omar HA (2013). The impact of the internet on the sexual health of adolescents. Internet addiction: A public health concern in adolescence (pp. 133-138). Hauppauge (NY): Nova Science Publishers.

Strasburger V (2010). Council on Communications and Media, Academy of Paediatrics. Children, adolescents, substance abuse, and the media. Journal of Paediatrics 126(4):791-799.

UNICEF (2018). A Child Rights-Based Approach to Food Marketing: A Guide for Policy Makers, New York; UNICEF.

Victor SC, Amy B, Jordan, Donnerstein (2010). Health effects of media on children and adolescents. Pediatrics 125(4):756-767.

Vijayapushpam T, Maheshwar M, Rao DR (2014). A comparative analysis of television food advertisements aimed at adults and children in India. International Journal of Scientific \& Engineering Research 2(6):476-83.

World Health Organization (2018). Report on Adolescent Health- the missing population in Universal Health Coverage. Available at https://www.who.int/pmnch/media/news/2018/Adolescent-HealthMissing-Population-in-UHC 